\title{
The Third-Generation Armenian American Writers Echo the Quest for Self-Identity with the Genocide at Its Core
}

\author{
Rubina Peroomian \\ University of California
}

$\mathrm{T}$ he Armenian Genocide in the Ottoman Empire is almost a century old, but unanswered questions persist: why did it happen? Why the world let it happen? Why this terrible injustice has not been acknowledged and restored? Obsession with the collective cataclysmic experience keeps surfacing in Armenian literature, in this case the Armenian-American literature. The Turkish denial of the crime fuels this obsession. Then, there is also the vague image of a lost homeland that kindles a sense of deprivation even in the most integrated and acculturated American-Armenians of the present generation. The Armenian-American Genocide literature-narrative prose or poetry, eyewitness accounts, memoirs - reflects the interconnection of the Armenian Genocide and the Armenian-American self-image or identity.

Looking into the past, searching for one's roots, in other words, exploring ones ethnic identity and sense of belonging to the past, to history shared by other members of the group grew deeper under the influence of a trend in the United States in the 1960s and 70s mostly among the African-Americans. The American culture of the time facilitated group affiliation and identification. The Armenian past was obviously associated with the massacres and deportation, thus becoming the source of self understanding, self-consciousness, and selfidentity. The catalyst for this process was the transmitted horrifying memories of the massacres and nostalgic reminiscences of the Old Country, or the homeland lost, the pain of adjusting to the New World that inundated the Armenian press of the 1920s and 30s. Mostly wanting aesthetic value, this literature functioned, however, as a source of knowledge and inspiration linking the generation growing up in America to the Armenian past.

Curiously, the second-generation survivors to a large extent served as silent transmitters, in some cases passively, in others reluctantly bridging between their parents and the next generation. They too had to face the challenges of the New World. The burden of survival consumed them too, as they fought to get ahead and prove themselves against the "failure" of their parents and against the prevailing prejudice. David Kherdian writes of his mother "Victim of America who escaped the Turkish Genocide" (Kherdian 1970). ${ }^{1}$ It is certainly true that no matter how hard the survivors tried to make a healthy and happy environment, free of the scars of the past for their children to grow in, they did not succeed. Or in other cases, these children grew sick and tired of their parents' incessant tragic stories; they turned a deaf ear, and silenced their parents' urge to relieve the burden of memories by speaking out and telling their painful stories. "Mother, if you are not going to speak English, then don't speak at all. And so mother didn't," Victoria remembers (Foston 2001:98). In all cases, even if these children were shut out or they shut themselves out of their parents' traumatic past, its psychological effects were impressed upon them. Historical memory was transmitted. 
In the last thirty years or so, there is an upsurge of memoir writing. Decades after the immediate Armenian language responses, survivors in their old age and with the encouragement of their children began to write:

- Kerop Bedoukian's memoir, Some of Us Survived (1979) from the unique perspective of a nine-year-old boy from Sivas observing the world of atrocity around him.

- Alice Muggerditchian Shipley's memoir, We Walked Then Ran (1983), an unusual route of escape from the horrors of Turkish atrocities from their native Diarbekir to Kharbert, Dersim, Erzinjan, Erzerum, and then to Tbilisi, Baku, Astrakhan, up the Volga River, over the Arctic Ocean and the North Sea to Great Britain and freedom.

- John Minassian's Many Hills Yet to Climb, John (Hovhannes), native of Gurun and Sivas, motivated by the words of an older inmate in the Turkish prison: "We may not survive, but your generation has a call and a duty" (Minassian 1986:3-4). Yes, the call and duty of telling the world.

- Bertha (Berjuhi) Nakshian Ketchian wrote her story, at the behest of her son and daughter. In the Shadow of the Fortress: The Genocide Remembered. In the introduction she writes, "We - the survivors - are living eyewitnesses of the Genocide of Armenians by the Turks. What was documented in writing and pictures at the time is now being denied" (Nakshian Ketchian 1988:ix). So she writes to fight against the denial and believes, that "recognition of the crime does not bring the victims back, but it eases somewhat the pain of the living" (Nakshian Ketchian 1988:x).

- Hovhannes Mugrditchian of Lapajle (Baghché) wrote his memoirs in Armenian, and his son Paul Martin, had them translated into English as To Armenians with Love, The Memoirs of a Patriot. "For our children and grandchildren, we knew we had to have an English-language version," (Mugrditchian, 1996:xvii-xviii) Paul Martin believed.

Through these memoirs - of which only a few examples were mentioned - we hear the slaughtered nation speak. Each tells the story of a life experience that in the general sense is similar to others-no matter where the story originates, whether in Sivas, Kharbert, Erzerum, Husainig, Mezré, or elsewhere. At the same time, the unique details of each writer's story lights up a dark corner of the calamitous story of the Armenian Genocide: A torturous journey, a first encounter with the sight of rotting corpses, an alarming signal foreboding the end they themselves might be destined to meet, then the looters snatching all belongings, the chettes smashing dead small children, kidnapping pretty girls, raping women young and old, and dead corpses too, the tearing open of the bellies of pregnant women and throwing the fetus in the air or smashing it against a rock, the victims screaming in horror and pain, pleading for mercy, and the zaptiés looking on all this with pleasure or indifference at best, or themselves participating in the carnage. It is not easy to read these stories. These macabre scenes of cold-blooded murder and rape, starving children, and the unscrupulous orgies of Turkish officers feasting on Armenian maidens can leave the reader depressed and bewildered for days. These are books that, as Kafka says, "come upon us like ill-fortune and distress us deeply, like the death of one we love better than ourselves, like suicide" (Rosenfeld 
1988:18). ${ }^{2}$

The first generation Genocide literature, as well as the oral or written testimonies, served as raw material to inspire literary responses by the second and third generations and was transformed into a structured, organized memoir or a novel even poetry with a specific form and style, embellished by the author's artistic qualities and rich imagination.

Peter Najarian's Voyages (1971) is the site of the painful conflict and attempted reconciliation between the past and the present. It is the ever-present past constantly pressuring the present, defeating the efforts of the characters to rise above the unhappiness, to find their identity and adjust to their adopted country. Najarian's Daughters of Memory (1986) is again a search for identity and an effort to hold on to the memory of the Genocide. The conversations and reminiscences between a group of old Armenian women who experienced the Genocide in their youth, provide the background and trace the history of the Armenian Genocide.

David Kherdian also gives one of the earliest examples: The Road from Home: The Story of an Armenian Girl (1979), a touching account of young Veron Dumehjian, David's mother, and her miraculous survival.

Efronia: An Armenian Love Story (1994) is another example. Efronia Katchadourian's memoir of some 500 pages was translated into English by her son and then turned into a nicely-wrought piece of imaginative literature, a love story, by her nonArmenian daughter-in-law, Stina Katchadourian. ${ }^{3}$

Gradually, after the parent's death, through fragmented memorabilia left behind, or because of renewed interest and the usual reverence that creeps into one's heart toward a dead parent, the son or daughter discovered the full scope of the source of that unexplained pain and disposition, the tremendous burden of memory that had weighed so heavily upon the parent.

Virginia Haroutounian's Orphan in the Sands (1995) is the story of the author's mother, who only in the final days of her life shared with her daughter her terrible ordeal during and after the Genocide. It is also the story of the daughter, who resented her mother's strange behavior and all her life strove to adjust to it, only to learn in the end that it was the Genocide and its aftereffects that caused her unfathomable, peculiar behavior, ruining her mother's and her own life.

David Kherdian speaks of the same experience with his father (1970):

Why have I waited until your death to know the earth you were turning was Armenia, the color of the fence your homage to Adana, and your other complaints over my own complaints were addressed to your homesickness brought on by my English.

(Kherdian 1970) $^{4}$ 
In another poem, Kherdian again describes his father, who "always carried a different look and smell into the house when he returned from the coffee houses in Racine":

Years later, reading the solemn and bittersweet stories of our Armenian writer in California, ${ }^{5}$ who visited as a paperboy coffeehouses in Fresno, I came to understand that in these cafes were contained the suffering and shattered hopes of my orphaned people.

(Kherdian 1970)

Agop Hacikyan knew very little of the Armenian past when he was growing up in Istanbul. His parents, both survivors of the Genocide, kept silent, and their reason, obviously, was not only psychological but also political. The new regime in Turkey had successfully suppressed the historical memory of its citizens. But the conspicuous silence and the occasional references to aksor (meaning exile, as survivors referred to the deportation) were factors that spurred Hacikyan to write a series of novels decades later, beginning with Tomas (1970) and Eté sans aube (1991) which was translated into English as A Summer Without Dawn (2000). And here is the epitomization of the answers to why it happened, scratched on the wall of a Turkish prison, "The just are condemned because of their race, their language and their faith, and here they await their death" (Hacikyan 2000:142).

Helene Pilibossian knows that she is a product of her parents' traumatic experience with the Old Country present in her subconscious. In one of her collections of poems titled History's Twists: The Armenians (2008) she travels through the bumpy roads of Armenian history "with the stories of the desert of Der-el-Zor so long ago" taking her to the labyrinth of "the scrambling Turkish will" showing her the "diaphanous spider web" that is the survival of the nation built on Remembrance. ${ }^{6}$

One way or another, the entire nation was bearing the effects of victimization. For Diana Der-Hovanessian, all Armenians are survivors of genocide. It does not matter whether or not one has lost family members in the death marches. "We are children of Der Zor," she writes.

Even though your mother was a baby

in Worcester, and safe

and your father a young soldier

in Mourad's mountains

and you a generation from being born,

...................

even without a single

relative who lived to march,

lived past the march. We are children of Der Zor.

(Der-Hovanessian 1987) $^{7}$ 
Is it possible?

Elie Wiesel says, "Yes, one can live a thousand miles away from the Temple and see it burn. One can die in Auschwitz after Auschwitz" (Berger and Berger 2001:1). ${ }^{8}$ The transgenerational psychological impact can shape the outlook and the individuality of succeeding generations and can be as deep and effective as to produce the feeling of dying in Der El-Zor without having been there.

The burden of tragic memories had been indirectly yet effectively transmitted, for it fits perfectly into the family atmosphere and the parent-children relationship experienced by the generation born to the survivors of the Genocide. The result was a small but valuable output of genocide literature.

The third generation responses are crafted from a distance of time and space without direct experience of the Genocide, with the impetus of a transmitted pain or a suddenly discovered past, bearing the influence of different cultural, religious, environmental, and sociopolitical factors, and within different levels of skill and understanding of the poetics of genocide. They are created with a variety of thrust and motivation: they may seek a catharsis in order to relieve the transgenerational pain, they may strive to establish further factual evidences in order to combat denial, or they may reflect the author's unabated frustration with the continuing injustice and the conspiracy of world silence. For all intents and purposes, these responses encompass the echoes of the nation's collective psyche shaped by the violence, the pain of dispersion, the effects of self-accusation, the search for identity or the struggle to cope with a dual identity, the effects of the past and present roles of the perpetrators and world bystanders.

To elucidate my point here I would like to underline three examples of motivation and purpose in regards to the $3^{\text {rd }}$ generation writers.

\section{A Self-assumed Mission}

In Rise the Euphrates (1994), Carol Edgarian skillfully blends the facts of the Armenian Genocide and the traumatic experience of the survivor generation with the attractions and fun and multiple opportunities that American culture can offer a thirdgeneration Armenian teenager (Edgarian 1994). It comes through clearly in Edgarian's work that no matter how deeply assimilated to the culture and lifestyle of the mainstream, no matter how aloof from the Armenian past, this American-born generation still carries traces of the wounds of the Genocide. Her work stands as a bulwark against denial.

Mae M. Derdarian speaks with the voice of her grandmother, adding her own imagination and artistic skill to create a work of art, Vergeen: A Survivor of the Armenian Genocide, based on a memoir by Virginia Meghruni. The author's motivation to embark on such a difficult project was not only to tell the story of her grandmother, but also, "to immerse the reader in her story and to refute historical revisionists who deny and distort the facts of the Armenian holocaust." With her story, she cries out to the world and to the deniers, "I was there! I was an eyewitness! I was a victim!" (Derdarian 1996).

Lines in the Sand, a novel by Thomas A. Ohanian, subtitled "Love, Tragedy, and the Armenian Genocide". It is, according to the author's note, "a work of fiction in a background of history." It is the Armenian Genocide fictionalized, wherein public personages appear in their historical roles while fictitious characters people the stage as 
the devastating story of the First World War unfolds. Notably, the novel ends with a reminder of Hitler's statement, who remembers today the annihilation of the Armenians, and the news of the Jews being killed, and then another juxtaposition: "The little black lines of news type became trains carrying Jews, moving through the dense forests, breaking and cracking off branches that fell into the snow. And as the wheels swerved along the curving track the snaking train turned into shifting, moving people. Walking, in the desert. Lines of people. Lines in the sand" (Ohanian 2001:300) Clearly, a reminder to the world that forgetting past atrocities is the best encouragement for future atrocities to occur.

Mariam Manoukian and her daughter, 13-year-old Elize had a different mission when they set out to revive the old pages of a diary left by Mariam's grandmother Hranoush when she was 13 and caught in the turmoil of the defense of Van and the entire population's torturous trek to Eastern Armenia during the Armenian Genocide: On the other Side of Mount Ararat, a Story of a Vanished City (2005). This mother and daughter team intended to write for young English readers to acquaint them with Armenian history and the Genocide.

\section{A Sudden Discovery of the Past}

Peter Balakian's Black Dog of Fate (1998) is a perfect example of a journey into the past after a sudden discovery of a family secret tied with the Old World. Balakian is motivated to also record the history of the Armenian Genocide. The result is a mélange of memoir and documentation. It is an attractive source of reference for non-Armenians and new-generation Armenians. It is, as the author himself puts it, a "polyphonic, multilayered memoir" in which "personal discovery and history merge." Here, the Armenian component is gradually extracted from a nebulous memory hole to become an important dimension in the American-Armenians' self-identity.

These historical interjections are vivid examples of history and memory juxtaposed. Besides the jarring change of style, from the inherent dryness and factuality of the one to the somber elegance of the other, the juxtaposition reveals the difference between the two in terms of shaping the image of the Armenian Genocide in the reader's mind. This is the intrinsic value of genocide fiction or symbolic poetry in the understanding of the Armenian Genocide and as elucidators of universal truths that lie at the roots of historical facts, putting inconceivable realities into human perspective (Peroomian 1996:22-25). Many historians reject the role of artistic literature in assisting readers to grasp the meaning of a historical event. Yosef Hayim Yerushalmi declares with dissatisfaction, "The Holocaust has already engendered more historical research than any single event in Jewish history, but I have no doubt whatever that its image is being shaped, not at the historian's avail, but in the novelist's crucible" (Langer 1991:51) Historians may disagree and may disapprove of the departure from historiographic methodology, but documents, statistics, and data do not provide the full story. It is not possible to penetrate the world of the Armenian Genocide without reading the memoirs, the artistic literature, and the eyewitness accounts.

Vickie Smith Foston's amazing journey into the past is another example. She sets out 
to unveil a well-kept family secret that involved her grandmother, Victoria's (also her namesake) suicide half a century earlier. In the course of her cumbersome research, Foston comes across the astonishing truth about her roots, heritage, and background. In contrast to the false information handed down to her about her father's grandfather being French and her mother's family originating in Italy, she finds out that her ancestors came from Mush, pure-blooded Armenians who escaped the Turkish persecutions and massacres of 1894-96. Not exactly a Genocide survivor's account, Victoria's Secret: A Conspiracy of Silence (2001) is the story of an immigrant family in which the conflict between forgetting the past and assimilating into the mainstream on the one hand, and adhering to ethnic identity and traditions on the other hand creates family quarrels that deepens dangerously. And although assimilation is the name of the game, national pride and ethnic consciousness, nonetheless, find expression in deeds and behaviors, in a family project, a collective work of art, a beaded tableau of Mother Armenia lamenting over the ruins of the homeland, or in a charcoal landscape of Armenia with Mount Ararat in prominence.

In the course of Foston's quest, the story of the Armenian people and the process of the Turkish annihilation of the Armenian population of the Ottoman Empire unfold. This sideline story, however, is not given the chance to develop within the context of the main story. Insertions are made arbitrarily in the form of reminiscences of a tradition passed on to the author's mysterious grandmother by her mother, Foston's great-grandmother. These passages, which rather sound like history lessons the author herself has learned, are fortunately fairly brief and do not detract too much from the novel's otherwise solid structure. The same technique breaks the smooth flow of the narrative in Peter Balakian's "Black Dog of Fate" (1998).

Reminiscences become more plausible and flow more smoothly and naturally when Foston relies on the memories of genocide survivors living in Fresno, where refugee women and children often gathered in the streets to tell their stories of starvation, rape, murder, pain, and suffering, and above all their determination to survive. "I was lost in these stories as if they were my own," says Foston's mysterious grandmother, Victoria, from her grave and continues, "I am sure this group of family and friends had no idea of the impact these images would have on my life" (Foston 2001:95). This key sentence embodies the reality of the widespread psychological effect of the Armenian Genocide not only in the sense of vertical ascension, that is, the transgenerational impact, but also its horizontal spread, involving Armenians whose lives were not directly touched by the catastrophe.

Micheline Aharonian, Marcom, in her novel Three Apples Fell from Heaven (2001) attests that her mother was raised in Beirut on stories of the genocide. "Afternoons were spent during her childhood listening to her mother and the other ladies of the neighborhood remembering the atrocities." ${ }^{10}$ Micheline's mother married an American and moved to America in part to leave the old world behind, and she habitually refrained from speaking of the gloomy stories she was raised on, a typical second-generation reaction. On occasion, however, few sentences would slip out of her mouth: "The Turks pulled out their fingernails, beat the soles of their feet. . . Pregnant girls had their babies 
torn from their bellies. Nané [Micheline's grandmother] saw them march to their death."

Micheline knew very little about her family and the history of her people. She says that was a reason she began to write what would be her first novel, "I had an incredible need to know my family history, to figure out my place." She wanted to fill in the world behind the phrases she had heard here and there about her grandmother, that brave woman who had walked the death marches as a young girl and saved her sister and three younger brothers and raised them in Beirut. She wanted to know about Kharbert and Mezré which her grandmother had called home.

Unlike other survivors' life stories, fictionalized or recounted, Three Apples Fell from Heaven is not a straightforward narrative about the survival of Micheline's grandmother Anaguil (Nané), but an abstract and complex tapestry wherein the voices of the dead and the living intermingle to evoke an abstract tableau of suffering and death. In this multilevel narration, we come across the story of Sarkis who is gradually going mad in the dark attic where his mother has hidden him in woman's clothes to save him, her last son, from the gendarmes. We share the feelings of Kamil, a Turkish soldier enduring the harsh winter on the Russian front. Kamil deems it his duty to fight for his homeland, but he has no desire to conquer Russian soil. He is fighting against giavours, the infidel Armenians of Anatolia, who "joined the battle with our age-old enemy and tried to strike our army in the back ... who became rich off of us. They have always been the money-grubbers, merchant vultures. They stab us in our naked backs, they laugh at our chapped feet. We lost Greece, Bulgaria, and Serbia to the Christians. Will we lose again brothers?" (Marcom 2001:124). Another character is Rachelle, whose sad story weaves another shade of gloom into the morbid tapestry. Her fate is strikingly similar to that of her biblical namesake, who had sworn to Jacob that "she would die without children, and she died on the birthing stool". In the novel, Rachelle is cognizant of that tradition, thinking as she plunges to her death in a dark well "how my name had pressed its regimen onto my skin, deep to the very bones" (Marcom 2001:36). The Judeo-Christian tradition is very much alive in the minds of victims and at time of death it becomes the only source of meaning and explanation. When Sarkis, the young man hiding in the attic, tries to find meaning in the atrocity to which his people are subjected, a Judeo-Christian explanation of catastrophe is again proposed in the concept of sin and punishment: "Did we do some thing (evil) to bring this down upon our heads?" (Marcom 2001: 46). Yet Sarkis is not bound to believe in that explanation wholeheartedly. Even if that is God's will, and the Turks are only the executors of that will and the tool of the punishment, what is it that enables them to commit such a crime? How they must hate Armenians to be able to kill a neighbor with whom they have shared bread; to kill a faithful customer who frequented their shop; to kill a fellow college student, with whom they had sat and studied, or watched a soccer game together, or shared the poetry of Whitman whom they both adored.

Then there is Hagop, another victim of injustice, standing hands tied in the police station with others like him, not knowing for what crime he is being detained. This was an ordinary scene in those days, but Micheline's imagination takes flight to give it the form of abstract art. Hagop hears the whispering of men, "not of the bound men who stand at his side, but of the Armenian men who have haunted these valleys and plateaus 
and plains for centuries. He thinks he can hear their handless spirits saying to him in the spring night, Brother, do you believe a few thousand years of history make any difference to armed men?" (Marcom 2001:103).

The success of these memoirs turned into novels or other sub-genres of genocide literature in prose and poetry can be attributed to the fact that they are being produced within the conventions of Western culture. They are palatable to Western taste and interest in horror stories. The third generation poet or writer has mastered the criteria. As Arpiné Konyalian Grenier terms it, the new writer "faces the tragedy, accepts it, mourns it and transcends it." She later adds, however: "It is tricky and slippery to face emotion and express it in unadulterated fashion" (Grenier 1993: 26-27). It is indeed a challenging task, for it is sometimes impossible not to succumb to the waves of irrepressible emotion. And this will bring me to another subgenre in the $3^{\text {rd }}$ generation responses.

\section{In the Grips of the Past}

Leonardo Alishan, a third-generation Iranian-Armenian-American writer, was never able to transcend, or rather he never tried to transcend the tragedy that was his grandmother's, the tragedy that became his fate at the age of nine. His strongest literary creations are about his "Granny" and "bearing witness to her agony." He shares her agony; he is part of it: "I try to be a spectator of that tragedy which culminated in a London hospital room in 1978 where Granny saw Turkish horsemen around her bed before she died. But, alas, I am not the spectator. I am a character caught in that play which never, never, never reaches its equilibrium" (Alishan 1992:352) Alishan remained gripped by the nightmare of genocide. His Granny, "Gayané, the living martyr," as he pictured her, governed his life and his emotions. She was a constant presence in his dreams, in his waking thoughts. It was through his grandmother, as it is the case of most third-generation writers, that Alishan saw the Armenian suffering, the Genocide:

In the center of my dream

there is a church of stone in Van

sealed from outside

exhaling screams and smoke from the inside,

its congregation of Armenian folk

replacing the candles with their flesh.

There is a church in my dream

made with the bones of dead gods,

babies and parrots' prayers;

always, all night, in flames

but never burning to the ground.

And in the church burns a statue of Mary

With my Granny's face, wax dripping down her eyes

drop by drop, on the skin of my dreams.

$\left(\right.$ Alishan 2002) ${ }^{11}$ 
Leonardo Alishan was himself a victim of the Armenian Genocide who carried upon his frail and weak shoulders the immensity of the traumatic past personified in his grandmother all his life until his tragic death/suicide in 2005. He was only 54.

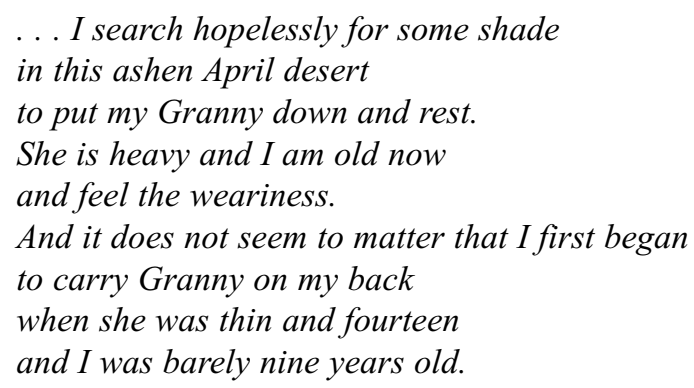

(From an unpublished poem 2002) $)^{12}$

The replay of the tragic memory of the Armenian Genocide, even though not at peak intensity, nor as devastating as it was for the first-generation survivors, has been transmitted to subsequent generations and is inspiring literary creations. The topoi associated with the Genocide appear as fragmented images imposing themselves upon everyday life in the New World. Many of Peter Balakian's poems in Sad Days of Light (1983) illustrate this duality. Through a commingling of images past and present, Balakian registers 1915 in his grandmother's mind (Shirinian 1990:110-115). ${ }^{13}$

\section{To Conclude}

North American-Armenian writer-critic Lorne Shirinian observes, "1915 functions as a symbol through which Armenians have knowledge of themselves and see themselves. Having survived genocide, not only do they have to believe in themselves, but they have to convince others of their existence. Armenian Diaspora literature is an expression of this necessity" (Shirinian 1990:60).

Indeed, the quest for self-identity takes imaginative literature along different paths; yet the Genocide and the reconstruction of the memory of it remain at the core as the leitmotif. This is true in the case of the second-generation survivor writers, and examples are many. The intensity of this struggle for an Armenian identity, however, does not necessarily exist to the same degree in all American-Armenian communities. In some cases, the struggle is only that of the intellectual elite, and the wound of the Genocide bleeds through the literary works they produce. The third generation is still caught in that struggle and their responses emerge from the attempt to confront the Genocide in order to grasp its historical and psychological impact, and to uphold memory with which to relate and identify. In this context, I would love to have the time to discuss Nancy Krikorian's "Zabelle" and her other novels, Mark Arax's "West of the West", Aris Janigian's "Riverbig", Nancy Agabian's "Me as Her" and more. I would want to expand this study and take up the genre of dramaturgy reflecting the effects of the Armenian Genocide. But I will stop here and make my last comment: 
The literary representations of the Armenian Genocide will continue to shape the understanding of this unresolved injustice for generations to come. They will function as the most effective transmitters of memory, shoring up commitment to the national struggle. Indeed, it is the artist's creative power that can capture the unthinkable horrors of the genocide and bring them into the arena of the reader's imagination. In spite of Yehuda Baur's warning against the Holocaust being understood through the works of imaginative writers and his labeling this kind of understanding as "metaphysical comprehension," in spite of Yerushalmi's dissatisfaction with the image of the Holocaust being shaped by novelists, there is an undeniable truth in the power and intensity of the impact that a literary representation of genocide can make and the crucial role it can play (Young 1988:7).

Emil Fackenheim states, to renew the past for present life has always been an essential obligation of historians, philosophers, and theologians (I would add, of the literati as well). And never before has this task been so indispensable and so difficult (Morgan 1997:172). Therefore, I would like to submit that responses to the Armenian Genocide will stand as a monument to the memory of the Armenian tragic past, to the Armenian aspiration to become a nation again, and to find a way to resolve the tragedy in order to make national survival and perpetuation possible.

\section{Notes:}

1. The line is from the poem "A Family of Four" by David Kherdian (1970) from the collection, On the Death of My Father and other Poems.

2. Cited in Alvin Rosenfeld, A Double Dying Reflections on Holocaust Literature (1988).

3. For a brief analysis of this work, see the review by Rubina Peroomian, Journal of the Society for Armenian Studies 7 (1994): 205-08.

4. This poem ("For my Father") and the poem quoted next ("My Father") are examples of many which resonate the ineffaceable, tormenting memory of the Genocide indirectly transmitted to the author through his father to whom the collection Homage to Adana (1970) is dedicated.

5. The reference to "our Armenian writer in California" is to William Saroyan.

6. For a brief analysis of pilibossian's poetry, see the review by Rubina Peroomian, Journal of the Society for Armenian Studies 18, 2 (2009): 145-48.

7. The quoted piece is from part 2 of the three-part poem "Tryptich" titled "Why Sand Scorches Armenians." See About Time (1987), p. 14.

8. For the citation of this tale by Uri Zvi Greenberg and Elie Wiesel's commentary on it, see Alan L. Berger and Naomi Berger (2001).

9. Quotation from The Chronicle of Higher Education, June 12, 1998, p. B7.

10. This and the next citation are from Marcom's testimonies on the occasion of the publication of her book in the UC Berkeley Armenian Alumni Newsletter.

11. From an unpublished poem, titled "ECCE HOMO." 
12. "Growing with My Heritage (For Two Victims of the Armenian Genocide)," fourth in the sequence of four poems he titled "Victims: The Return of the Cruelest Month." He wrote this sequence in April/May, 2002, unpublished.

13. For an analysis of these images in "The History of Armenia," see Lorne Shirinian (1990).

\section{References:}

1. Alishan, L. (1992) An Exercise on a Genre for Genocide and Exorcism. // The Armenian Genocide: History, Politics, Ethics. / Ed. by R.G. Hovannisian. New York: St. Martin's Press.

2. Balakian, P. (1983) Sad Days of Light. New York: Sheep Meadow Press.

3. (1998) Black Dog of Fate. New York: Broadway Books.

4. Berger, A.L. and Berger, N. (Eds.) (2001) Second Generation Voices, Reflections by Children of Holocaust Survivors and Perpetrators. Syracuse, NY: Syracuse University Press.

5. Derdarian, Mae M. (1996) Vergeen: A Survivor of the Armenian Genocide. Los Angeles: Atmus Press.

6. Der-Hovanessian, D. (1987) About Time. New York: Ashot Press.

7. Edgarian, C. (1994) Rise the Euphrates. New York: Random House Books.

8. Foston, V.S. (2001) Victoria's Secret: A Conspiracy of Silence. Sacramento: Victoria Lazarian Heritage Association.

9. Grenier, Arpiné Konyalian (1993). "The Apprentice in Exile: Toward an ArmenianAmerican Poetics," Aspora 1;1: 17-32.

10. Kacikyan, Agop, Christina le Vernoy and Joyce Bailey tr. (2000). A Summer without Dawn. Toronto: McClelland \& Steward.

11. Katchadourian, S. (1994) Efronia, An Armenian Love Story. Boston, MA: Northeastern University Press.

12. Kherdian, D. (1970) On the Death of My Father and other Poems. Fresno: Giligia Press.

13. (1970) Homage to Adana, Fresno: Giligia Press.

14.(1979) The Road from Home: The Story of an Armenian Girl. New York: Greenwillow.

15. Langer, Lawrence L. (1991) Holocaust Testimonies, The Ruins of Memory. New Haven and London: Yale University Press.

16. Manoukian, Mariam and Elize (2005) On the other Side of Mount Ararat, a Story of a Vanished City. Glendale, CA: Abril Book Publishing.

17. Marcom, Micheline Aharonian (2001) Three Apples Fell from Heaven. New York: Riverhead Books.

18. Minassian, J. (1986) Many Hills Yet to Climb, Memoir of an Armenian Deportee. Santa Barbara, CA: Jim Cook.

19. Morgan, M.L. (1997) To Seize Memory, History and Identity in Post-Holocaust 
Jewish Thought. // Thinking about the Holocaust, After Half a Century. / Ed. by A.H. Rosenfeld. Bloomington and Indianapolis: Indiana University Press.

20. Mugrditchian, H. (1996) To Armenians with Love: The Memoirs of a Patriot. Hobe Sound, Florida: Paul Mart.

21. Nakshian Ketchian, Bertha (1988) In the Shadow of the Fortress: The Genocide Remembered. Cambridge, MA: The Zorian Institute.

22. Ohanian, Th.A. (2001) Lines in the Sand: Love, Tragedy, and the Armenian Genocide. Published by Lines in the Sand Press.

23. Peroomian R. (April 1996) How to Read Genocide Literature, The Problematics, The Search for a Canon. // International Network on Holocaust and Genocide.

24. Pilibossian, H. (2008) History's Twists: The Armenians. Watertown MA: Ohan Press.

25. Rosenfeld, A. (1988) A Double Dying Reflections on Holocaust Literature. Bloomington and Indianapolis: Indiana University Press.

26. Shirinian, L. (1990) Armenian-North American Literature, A Critical Introduction: Genocide, Diaspora, and Symbols. Lewiston, Queenston, Lampeter: The Edwin Mellen Press.

27. Young, J.E. (1988) Writing and Rewriting the Holocaust. Bloomington and Indianapolis: Indiana University Press.

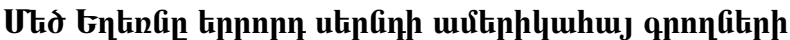 hfipfiupunuhujunưuti hpuipnıu}

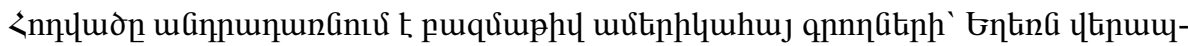

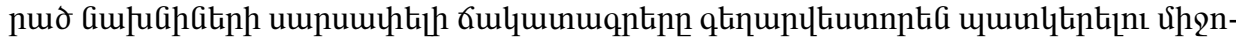

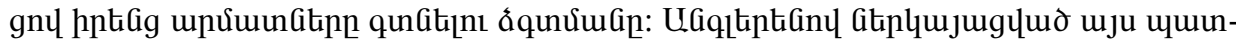

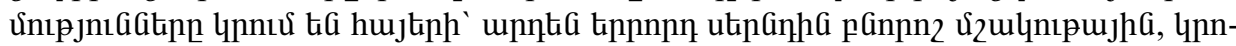



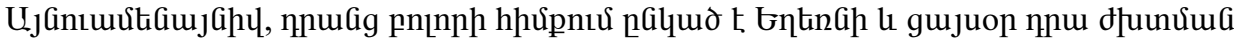

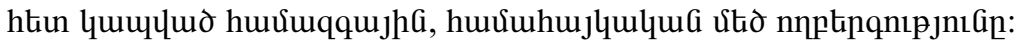

